Kateryna Osmolyk

Methodist of IT in Education Laboratory

Borys Grinchenko Kyiv University, Kyiv, Ukraine

k.osmolyk@kubg.edu.ua

ORCID: 0000-0002-1816-9299

Johan du Toit

Promoter and founder of the Electronic Social Art

jvdutoit@gmail.com

\title{
ELECTRONIC SOCIAL ART
}

\begin{abstract}
Modern education requires effective innovations that can help provide a system of necessary quality learning changes. Education must be not only comprehensive, stable and excellent, but also constantly developed to meet the challenges of a rapidly changing and unpredictable global world. The focus of educational innovation should be on the theoretical and practical teaching and learning process, as well as on students, parents, society and its culture. Technological applications require a solid theoretical basis, based on targeted, systematic studies and pedagogy. One of the most important areas of research can be modern technologies and innovations and their efficiency in education. With the development of modern communication and information technologies, the problem of their use in the educational process is quite important and actual. The use of Electronic Social Art as a combination of personal experience and art, presented with the help of new technologies, increases the interest in art and creates new opportunities for education. Electronic Social Art has great potential and implements informative, community, normative, creative, integration and mediatory functions.
\end{abstract}

Keywords: Electronic Social Art; Instagram; application; IC technologies; photo; dialogue; Art; Applifam

The first duty of an education is to stir up life, but leave it free to develop. M Montessori

Introduction. With the development of modern technology and e-learning, the problem of the cooperation and interaction between education and the latest technology is very significant and important. Today, with the development of technology and the use of the Internet, smartphones have become extremely popular. Actively created and used new programs and applications around the world. Instagram received a lot of awards as the best mobile app and the number of its users is growing every day. This is a huge potential and new opportunities for education and information sharing. Electronic Social Art was created to attract young people to art, exchange information, to dialogue and unite society with different views.

Analysis of recent studies and publications. In a social world, packed with new technologies for interaction between each other and media, a way to communicate in personal way is accomplished through sending someone digitally reproduced image whether a postcard or family photo (Hansen, Shneiderman, \& Smith, 2010; Sarvas \& Frohlich, 2011). New technologies help nonprofessional photographers to change images as they want. New applications are easy to use and they are in open access. Scientists that are busy working on implementation new technologies in educational process and working on the problem of visibility during teaching process are: John Amos Comenius, Andy Hargreaves, Johann Heinrich Pestalozzi, Hargreaves and Shirley, Friedrich Adolph Wilhelm Diesterweg, Konstantin Ushinsky, Michael Fullan, Tony Wagner and Ken Robinson.

The article's goal. The main goal of education today is personal development and growth. It's also important to teach the person to learn further in during the whole life. Search and use the best technologies and applications in the learning process is extremely important. The purpose of the article is to study Electronic Social Art, to reveal its potential and perspectives for its use in education. Find out the features and functionality of the Electronic Social Art. 


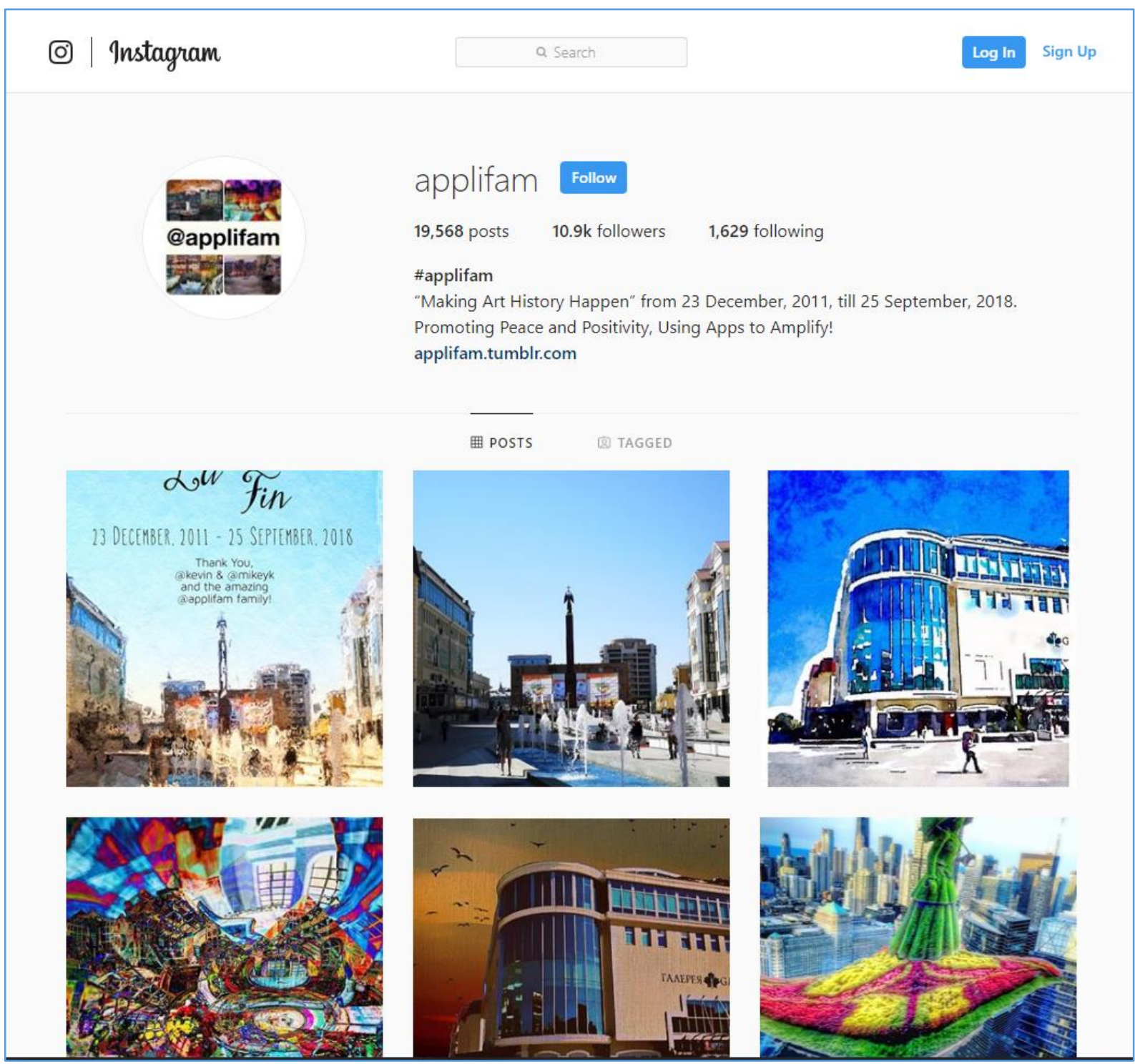

Fig.1. Official Applifam page in Instagram

\section{Electronic Social Art project:}

Johan du Toit is the promoter and founder of the Electronic Social Art Forum. It is nonprofit, French association, which was founded in 2012 to promote Electronic Social Art. The association, that based in Normandy, is developing a concept of combination mobile photography and electronic art shared via social media as a tool for mass-media and socially cohesive communication. (Fig.1):

Electronic Social Art is an experience created through a mobile and web-based platform for the creative expression of visual images. It is the combination of personal experience and art presented with a help of new technologies. The electronic canvas is digitally composed from the studio of applications on mobile/tactile devices and experienced in the showroom of social media. Electronic Social Art is the part of electronic art.

It is created with the help of new technologies - that's why it is Electronic.

Social - because it unites society for the sake of a common goal - cultural cohesion via compassionate communication.

It is Art, because it speaks from and to the heart.

The word "photography" was created from the Greek roots $\varphi \omega \tau$ ó $\varsigma$ (phōtos), genitive of 
$\varphi \tilde{\omega} \varsigma$ (phōs), "light" and $\gamma \rho \alpha \varphi \eta ́$ (graphé) "representation by means of lines" or "drawing", together meaning "drawing with light". Photography brings light between past present and future. The mission of photography is to share the collective vision of society that allows integration of solutions into problem areas in order to nurture growth.

Also Johan du Toit started Applifam - the global community, which was founded and continue to grow since 2011. This popular Instagram community allows to edit and to share images without copyrights. First it was named Applified, but six month later its name was changed to Applifam, this name presents the process of amplifying photographs with the help of different apps for mobile devices: smartphones, Android, the iPhone and the iPad. The "fam" means family. Members of Applifam family every day post and change photos according to the suggested themes. Anybody can take part and work with the photo - adding his own images and associations on Instagram, using daily hashtag. It is daily 24-hour challenge. During this activities participants discuss Art - styles and artists, social end live themes, various applications and technologies, they analyze the concept of Electronic Social Art. Electronic Social Forum represents Electronic Social Art as a new modern way of Art and it is registered in France. Personally Johan du Toit has more than 100000 Instagram followers and each everyday publication receives more than thousand likes. There were organized more than ten exhibitions in France - Normandy, USA - Baton Rouge, Louisiana and in Ukraine - Kyiv.

\section{The Role of Electronic Social Art in social and everyday life:}

Mixed Messages: Opportunity and Restriction. When person edit new photo it means that he wants to share his ideas and life with others. It doesn't matter is it a post of new event or somebody's lunch. It is a new way of communication with the help of new technologies.

Despite the fact that the photographs have always been manipulated and edited, numerous computational methods that are easier to use in changing photos have changed our understanding of what can be achieved for image editing. In cases of snapshots, the usual and automatic editing applications have become commonly used tools for touching, cropping and enlarging images.

While improving personal photos may not raise direct ethical or practical problems, the simplicity of image changes that are traditionally used professionally and the public service to reflect reality is very important. Marchessault and Wasson reflect on what such corruption is related to history and our construction of reality. With the development of digital technologies the closest connection between the initial context and its photographic reproduction disappears. Digital technology makes changes uncertain and circular easier than in previous times. Images become less tied to the photographers and contexts, and more accessible through large news services, that's why ethical dilemmas arise more urgent than ever. (Kirillova, 2005, pp. 16-69).

But while journalists, historians and other people are doing virtual truth, others, takes a more relaxed view and points out that "the change dramatically increases your capabilities", suggests using Photoshop, notes that it can combine photos, move and delete items in a photo, and provide cosmetic aerography.

In 1989, Tim Berners-Lee decided to make the Internet public through the World Wide Web. In 1993, everything changed due to providing a graphical interface on the Internet. Printers and scanners, photo management software have become available, and e-mail has become widespread in 1990s - 2000s. Flickr, the photo sharing service launched in 2004, provides many opportunities for photo hunters and continues to grow, starting in March 2013, with 3.5 million new images downloaded daily. Cell phone cameras entered the market in the early 2000s, and in October 2013, 92\% of Americans owned mobile phones, 58\% owned smartphones with a camera, $18 \%$ of mobile phone owners use Instagram, $54 \%$ of the adult Internet users post original photos or videos online (compared with $46 \%$ in 2012), and $47 \%$ of adult Internet users take photos that they found on the Internet and "redirect them to sites 
designed to share images with many people." This was also more than in the previous year, when the number was $41 \%$.

The influence of ESA on growth of the interest in Art among youth. The taking of immovable and fixed images has become a new reality and it has changed how people and artists, saw the world. It had created new opportunities and ways for creativeness. Impressionism partly appeared as a reaction of artists to the newly created world of photography. Just as the Japanese style focused on everyday life, the photograph also influenced the impressionists' interest in capturing the "snapshot" of ordinary people who make everyday routine.

Studying the science of photography, artists have developed a number of new methods of drawing. And instead of competing with the ability to record a "moment of truth", Impressionists, such as Monet, presented what they saw in a completely different way - focusing more in detail on the light, color and movement it was Impossible with a photo. First society considered this pictures 'unfinished' and 'sketchy'. With time, these subjective observations became more accepted as work of art.

A common sign for the language of photography, film and television is not only the universality of his original picture, but also his eventfulness. Of course, the sign universality of the frame is wide used in photo, film and television works, where it is given features of the art image, drama scene, element figurative narration, and yet with all the transformations indicated in it that moment which is not and cannot be in "Art picture" created using the language of classical arts This is what is called eventfulness, and what distinguishes media culture from the culture of traditional, classical.

Media culture is social information that exists and are kept by the society through the use of sign media created by people. Electronic Social Art is part of modern media culture. Media culture is a multifunctional phenomenon, just like culture as a whole. This means that it has a unique role in the social system. Classification functions of culture, given in the writings of many researchers - philosophers, sociologists, cultural studies, ranges between six and fourteen. We would like to highlight only those important functions that characterize media culture, making it an important social factor upgrades.

The informative function certainly comes first. Since media culture is a collection of information and communication tools, we are dealing with social information that is carried by culture. Thanks to photography in society, it becomes possible to accumulate and multiply information.

The role of the information function in Electronic Social Art is enhanced by computer technology, which includes memory and information processing programs. Thus, modern media culture is the guarantor of the information support of society.

The role of the communicative function is that Electronic Social Art is communication: within society, between different countries, nations, social groups, etc. It is the communicative function of Electronic Social Art that makes it possible to act as a powerful catalyst for the dialogue of cultures, thanks to which cultural exchange takes place information in the historicalphilosophical and historical-literary context, and thus social progress is intensified. Communication is the most important aspect of the cultural activities of mankind. With its development, people have acquired unusually wide opportunities to transfer and exchange a variety of information. Electronic Social Art provides a wide opportunity for people to communicate in time and space, overcoming time and distance. The communicative function was implemented through exhibition in Kyiv. (Fig.2): 


\title{
EXHIBITION: SOLIDARITÉ by Electronic Social Art Forum
}

\begin{abstract}
The Electronic Social Art Forum is a non-profit, French association, founded by Johan du Toit in 2012 to promote electronic social art. Within the field of electronic art, electronic social art is an experience created through a mobile and web-based platform for the creative expression of visual images. The electronic canvas is digitally composed from the studio of applications on mobile \& tactile devices and experienced in the showroom of social media.
\end{abstract}
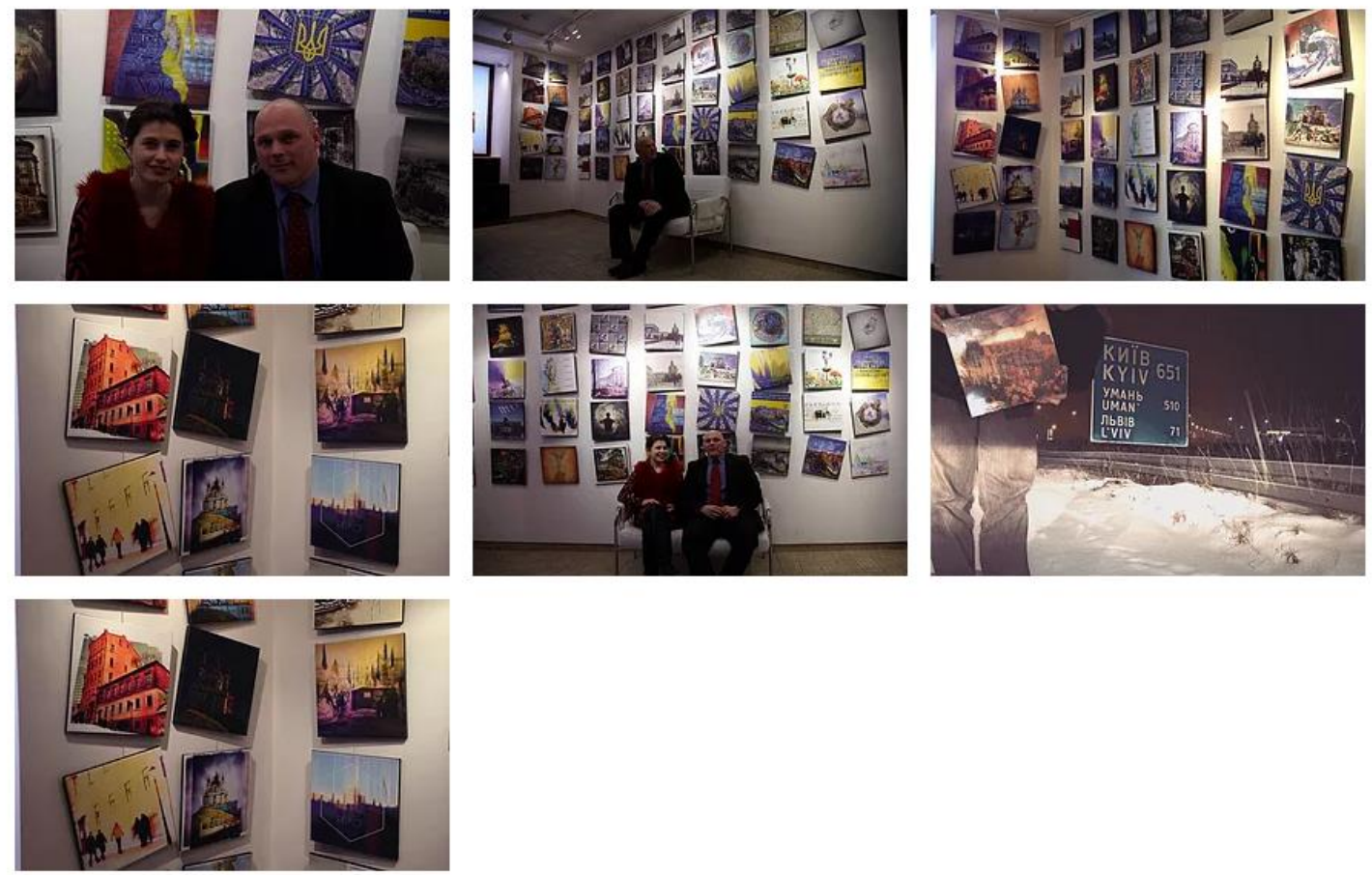

Fig.2. The exhibition of Electronic Social Art in Kyiv after events in Kyiv, in 2013-2014.

The normative (ideological) function is implemented through the fact that Electronic Social Art is involved in the process of socialization of the individual, in the transformation of social experience, knowledge, norms, and ideals, relevant to society. This also includes customs and traditions, etiquette and customs, laws and constitutional acts, everything that together forms such complexes, as law, morality, and ideology. All these are value orientations, without which the process of socialization of the individual is impossible, which ensures the preservation of society, its structure and the rules of life established in it. The society is transforming, changing, modernizing and changing the system of mass communications, whose role is intensified during crisis periods. It was this transformation and change of the communication system that cause the emergence of creating Electronic Social Art. Media culture is the most important factor in the socialization of the individual, determining its content, means and methods.

Relaxation function is associated with the need of the individual for physical and mental relaxation. Electronic Social Art fulfills this need.

Another fundamental function of Electronic Social Art is Creative function. That is shown through the development and transformation of the world and the surrounding life. With the help of information obtained from Electronic Social Art, a person expands his knowledge of the world, comprehending it from different points of view: philosophical, moral, economic, aesthetic, legal, and its curiosity, desire to know oneself in the surrounding world, to penetrate into the world is manifested. human being. Electronic Social Art gives you the 
opportunity to expand the boundaries of personal experience, thereby influencing the ideological attitudes, the process of personality formation.

Integration function. Culture unites peoples, social groups and states. It is truth. Preservation of cultural heritage, national traditions, and historical memory creates a link between generations. Electronic Social Art united the nations and regions, became a source of free exchange of information. Electronic Social Art has become a powerful factor in the integration of different cultures into a coherent whole. Differences in cultures during the combining of different traditions are exist. The integration function of Electronic Social Art is thus aimed at uniting cultures in the name of peace and mutual understanding between nations.

Mediatory function of Electronic Social Art as a social mediator, establishing links between the structures of society. It allows different social groups to communicate with each other and establish contacts. "The media is not power, but power, sometimes very significant, expressing public opinion and affecting real power, sometimes even limiting its possibilities." And from here a conclusion: Electronic Social Art is an intermediary between a society and the state, between society and the power. The mediation function is intensified in the period of the formation of a civil society based on the principles of democracy and freedom. In the same way as during the political events in Ukraine in 2014, representatives of Electronic Social Art actively covered them. (Fig.3):

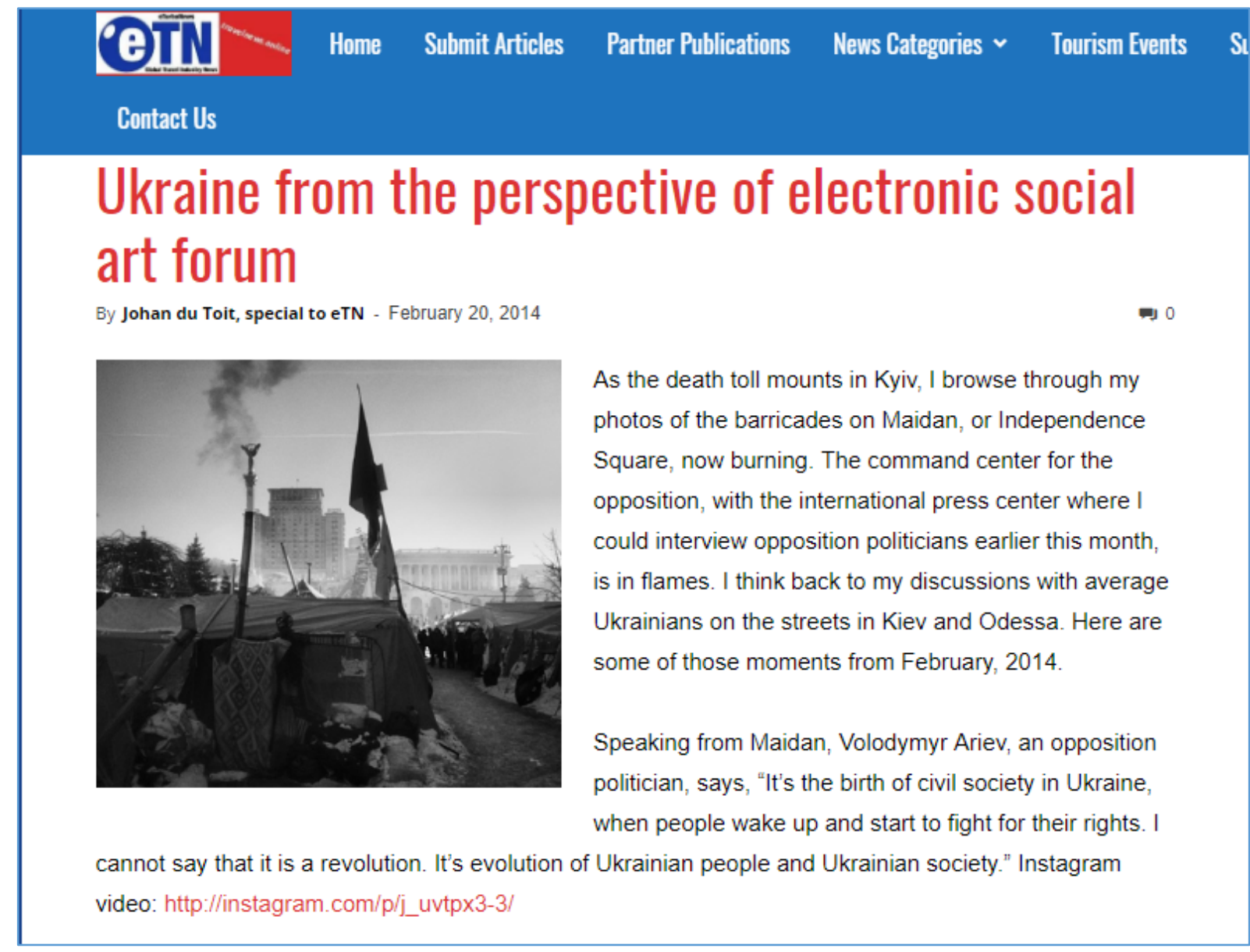

Fig.3. The article from Electronic Social Art, after events in Kyiv, in 2013-2014.

Conclusions. With the development of new technologies and with the growth of different application it's very important to use them in education. The use of Electronic Social Art as a combination of personal experience and art, presented with the help of new technologies, increases the interest in art and creates new opportunities for education. Electronic Social Art 
is the part of electronic art. It is created with the help of new technologies - that's why it is Electronic. Social - because it unites society for the sake of a common goal - cultural cohesion via compassionate communication. It is Art, because it speaks from and to the heart. Electronic Social Art has great potential and implement such functions: informative, community, normative, creative, integration and mediatory.

\section{REFERENCES}

Leslie-Jean Thornton (2014). The Photo Is Live at Applifam. Visual Communication Quarterly. Arizona State University $22 \quad$ Jul 2014. http://dx.doi.org/10.1080/15551393.2014.928147

Aspan, M. (2006). Ease of alteration creates woes for picture editors. New York Times. 2006, August 2014. http://www.nytimes.com/2006/08/14/technology/14photoshop.html

Carlson, D. (2003) The history of online journalism. In K. Kawamoto (Ed.), Digital journalism: Emerging media and the changing horizons of journalism, pp. 31-56. Lanham, MD: Rowman \& Littlefield

K. Kawamoto (Ed.), Digital journalism: Emerging media and the changing horizons of journalism, 31-56. Lanham, MD: Rowman \& Littlefield

Carlson, D. (2003) The history of online journalism. In K. Kawamoto (Ed.), Digital journalism: Emerging media and the changing horizons of journalism (pp. 31-56). Lanham, MD: Rowman \& Littlefield

Carlson, D \& Kawamoto K. (2003) The History of. Online. Journalism, Digital journalism: Emerging media and the changing horizons of journalism, 31-56. Lanham, MD: Rowman \& Littlefiel

Duggan M. (2013) Photo and video sharing grow online. Research Internet project http://www.pewinternet.org/2013/10/28/photo-and-video-sharing-grow-online/

Goh, D. H.-L., Ang, R., Chua, A. Y. K., \& Lee, C. S. (2009). Why we share: A study of motivations for mobile media sharing. Lecture Notes in Computer Science, 5820, 195-206.

Hart. A. (1998). Teaching the Media. International Perspectives. London: Lawrence Eribaum Associates Publishers.

Irvin S. (2005). Appropriation and authorship in contemporary art. British Journal of Aesthetics, 45 (2):123-137.

Jahns, R. (2013) 50 amazing photos on Instagram. https://hubpages.com/art/photographers-on-instagram

Stewart, C. (2013, October 2). The 30 best photo apps. Creative Bloq. http://www.creativebloq.com/design-tools/best-photo-apps-513764

Stewart, C. (2013, October 2). The 30 best photo apps. Creative Bloq. http://www.creativebloq.com/design-tools/best-photo-apps-513764

Stewart, C. (2013, October 2). The 30 best photo apps. Creative Bloq. http://www.creativebloq.com/design-tools/best-photo-apps-513764

Jahns, R. (2013). 50 Amazing photographers on Instagram. Squidoo.

http://www.squidoo.com/photographers-on-instagram

Jahns, R. (2013). 50 Amazing photographers on Instagram. Squidoo. http://www.squidoo.com/photographers-on-instagram

Jahns, R. (2013). 50 Amazing photographers on Instagram. Squidoo.

http://www.squidoo.com/photographers-on-instagram

Jahns, R. (2013). 50 Amazing photographers on Instagram. Squidoo.

http://www.squidoo.com/photographers-on-instagram

Jahns, R. (2013). 50 Amazing photographers on Instagram. Squidoo. http://www.squidoo.com/photographers-on-instagram 
Kirillova N. (2005). Media Culture: From Modern to Postmodern. Moscow: Academic project, 2nd edition. 16-69 (in Russian)

https://www.instagram.com/applifam/ \#applifam (in English)

https://www.instagram.com/?hl=en (in English)

Instagram. (2013). Terms of use.

http://instagram.com/legal/terms/\#

Instagram. (2014). Stats.

http://instagram.com/press/\#

Irvin, S. (2005). Appropriation and authorship in contemporary art. British Journal of Aesthetics, 45, 123-137.

Irvin, S. (2005). Appropriation and authorship in contemporary art. British Journal of Aesthetics, 45, 123-137.

Irvin, S. (2005). Appropriation and authorship in contemporary art. British Journal of Aesthetics, 45, 123-137.

@applifam - The Electronic Social Art Forum electronicsocialart.net/applifam.html (in English)

Text of the article was accepted by Editorial Team 19.11.2018

\title{
ЕЛЕКТРОНЕ СОЦІАЛЬНЕ МИСТЕЦТВО
}

\section{Катерина Осмолик}

Методист Центру вебометрії та інформаційних систем

Науково-дослідної лабораторії інформатизації освіти

Київський університет імені Бориса Грінченка, м. Київ, Україна

k.osmolyk@kubg.edu.ua

ORCID: 0000-0002-1816-9299

\section{Йоан дю Той}

Засновник Електронного Соціального Мистецтва

jvdutoit@gmail.com

\begin{abstract}
Анотація. Modern education requires effective innovations that can help provide a system of necessary quality learning changes. Education must be not only comprehensive, stable and excellent, but also constantly developed to meet the challenges of a rapidly changing and unpredictable global world. The focus of educational innovation should be on the theoretical and practical teaching and learning process, as well as on students, parents, society and its culture. Technological applications require a solid theoretical basis, based on targeted, systematic studies and pedagogy. One of the most important areas of research can be modern technologies and innovations and their efficiency in education. With the development of modern communication and information technologies, the problem of their use in the educational process is quite important and actual. The use of Electronic Social Art as a combination of personal experience and art, presented with the help of new technologies, increases the interest in art and creates new opportunities for education. Electronic Social Art has great potential and implements informative, community, normative, creative, integration and mediatory functions.

Сучасна освіта вимагає ефективних інновацій, які можуть допомогти забезпечити систему необхідних якісних змін у навчанні. Освіта повинна бути не лише комплексною, стабільною та відмінною, а й постійно розвиватися, щоб вирішувати проблеми мінливого та непередбачуваного світу. Основна увага навчальних інновацій повинна приділятись теоретичному та практичному процесу навчання, а також бути зосередженою на студентах, батьках, суспільстві та його культурі. Технологічні додатки вимагають міцної теоретичної б, заснованої на цілеспрямованих, систематичних дослідженнях та педагогіці. Однією 3 найважливіших напрямків дослідження може бути сучасні технології та інновації та їх ефективність у сфері освіти. 3 розвитком сучасних комунікаційних та інформаційних технологій проблема їх використання у навчальному процесі $\epsilon$ досить актуальною $\mathrm{i}$
\end{abstract}


актуальною. Використання електронного соціального мистецтва як поєднання особистого досвіду та мистецтва, представлене за допомогою нових технологій, підвищує інтерес до мистецтва та створює нові можливості для навчання. Електронне соціальне мистецтво має великий потенціал і реалізує інформативні, громадські, нормативні, творчі, інтеграційні та посередницькі функції.

Ключові слова: електронне соціальне мистецтво; instagram; мобільні додатки; інформаційно-комунікаційні технології; фото; діалог; мистецтво; applifam 